\title{
Propagation of three native Brazilian Piper species by cuttings and indole butyric acid
}

\section{Propagación de tres especies nativas brasileñas de Piper usando estacas y ácido indolbutírico}

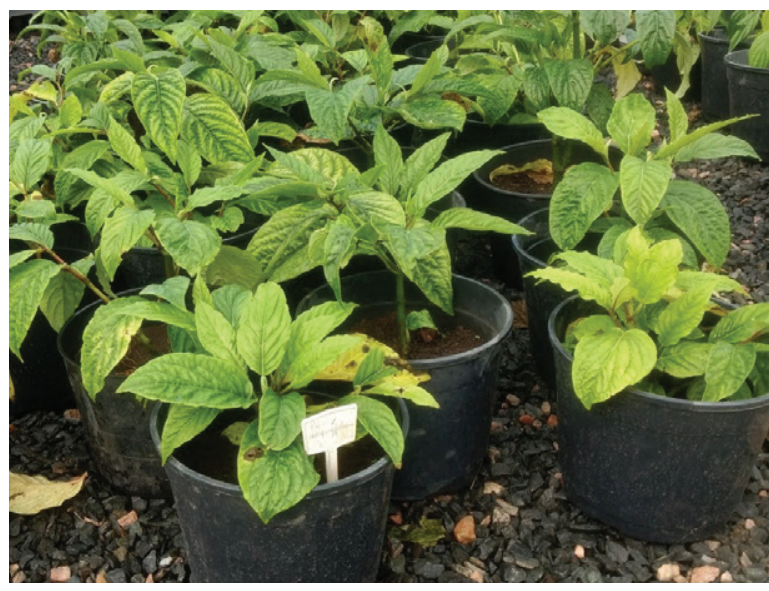

AUREA PORTES FERRIANI ${ }^{1}$

CÍCERO DESCHAMPS'

WANDERLEI DO AMARAL ${ }^{2}$

LUIZ EVERSON DA SILVA²

Propagated Brazilian species of Piper.

Photo: A.P. Ferriani

\begin{abstract}
Native Piper species present significant repellent, antimicrobial, inseticidal, anti-tumor and anti-protozoal biological activities. Studies on new species can discover unpublished potentialities and vegetative propagation for the development of cultivation protocols and reduce the natural extraction. The objective of this study was to evaluate the rooting of $P$. arboreum, $P$. cernuum and $P$. diospyrifolium stem cuttings with different treatments containing doses of indole butyric acid (0,500;1,000; 1,500; 2,000 and 3,000 $\left.\mathrm{mg} \mathrm{L}^{-1}\right)$. Branches were collected in the "Bom Jesus Biological Reserve", Parana state, Brazil. The cuttings, with a length of $12 \mathrm{~cm}$ and average diameter of $6 \mathrm{~mm}$, were placed in $53 \mathrm{~cm}^{3}$ plastic tubes with the commercial substrate Tropstrato $\mathrm{HP}^{\circledR}$ and intermittent misting. After 90 days, the survival, mortality, cuttings with new shoots, number and length of the three main roots were evaluated. The percentages of rooting reached an average of $67.5 \%$ for $P$. arboreum, $51.6 \%$ for $P$. cernuum and $50.4 \%$ for $P$. diospyrifolium. A positive effect in the treatments containing the plant regulator was observed for rooting development, percentage of cuttings with shoots and number of roots per propagule, but there were variations in the responses of each species. Leaf retention was an important factor for the adventitious rooting formation in all evaluated species.
\end{abstract}

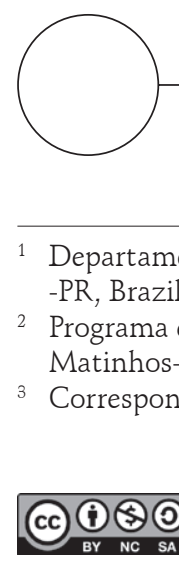

Additional key words: species domestication, biological activity, essential oil, plant growth regulators, plant propagation.

\footnotetext{
Departamento de Fitotecnia e Fitossanitarismo, Setor de Ciências Agrárias, Universidade Federal do Parana, Curitiba -PR, Brazil. ORCID Ferriani, A.P.: 0000-0002-2896-6427; ORCID Deschamps, C.: 0000-0003-0786-0532

Programa de Pós-graduação em Desenvolvimento Territorial Sustentável, Setor Litoral, Universidade Federal do Parana, Matinhos-PR (Brazil). ORCID Amaral, W.d.: 0000-0003-3979-4402; ORCID Silva, L.E.d.: 0000-0002-2332-3553

Corresponding author. aurea.portes@hotmail.com
} 


\section{RESUMEN}

Las especies nativas de Piper presentan importantes actividades biológicas repelentes, antimicrobianos, insecticidas, antitumoral y anti-protozoario. Los estudios sobre nuevas especies representan potenciales descubrimientos sin publicar y la propagación vegetativa es necesario para el desarrollo del protocolo de cultivo; además, reduce la extracción natural. El objetivo de esta investigación fue evaluar el enraizamiento de esquejes de $P$. arboreum, $P$. cernuum y $P$. diospyrifolium con diferentes tratamientos que contienen dosis del ácido indolbutirico (0, 500, 1.000, 1.500, 2.000 y $3.000 \mathrm{mg} \mathrm{L}^{-1}$ ). Ramas fueran colectadas en la Reserva Biológica Bom Jesus, estado de Paraná, Brasil. Los cortes con una longitud de $12 \mathrm{~cm}$ y el diámetro promedio de $6 \mathrm{~mm}$ se instalaron en tubos de plástico de $53 \mathrm{~cm}^{3}$ usando el sustrato comercial Tropstrato $\mathrm{HP}^{\circledR}$ y riego por nebulización intermitente. Después de 90 días se evaluaron las tasas de supervivencia, mortalidad y esquejes con nuevos brotes, número y longitud de las tres raíces principales. Los porcentajes de enraizamiento alcanzaron un promedio de 67,5\% para $P$. arboreum, 51,6\% para $P$. cernuum y $50,4 \%$ para $P$. diospyrifolium. Se encontró respuesta positiva de los tratamientos que contienen el regulador vegetal para las variables de enraizamiento, porcentaje de esquejes con brotes y número de raíces por estaca, pero hubo variaciones en las respuestas de cada especie. La permanencia de hojas fue un factor importante para el proceso de enraizamiento adventicio en las especies evaluadas.

Palabras clave adicionales: domesticación de espécies, actividad biológica, aceite esencial, reguladores de crecimiento vegetal, propagación de plantas.

Received for publication: 09-10-2017 Accepted for publication: 30-05-2018

INTRODUCTION

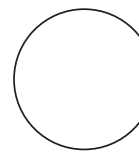

The Piper genus has 291 species, of which 184 are endemic to Brazil (Flora do Brasil, 2018). These species have been studied because of the production of essential oil with different biological activities (Pereira et al., 2008; Lopes et al., 2012).

Piper arboreum Aubl., known as "long pepper", "rosemary-angola", "fruit-of-bat", "jaborandi" and "jaborandi-from-river", is a perennial shrub with wide distribution, especially in the dense ombrophylous segment of Atlantic Forests (Guimaraes et al., 2006).

Several biological activities in $P$. arboreum result from the essential oil composition, such as a leishmanicidal action attributed to sesquiterpenes (Bernuci et al., 2016). The main constituint, sesquiterpene bicyclogermacrene, was reported in plants from the Federal District area by Potzernheim et al. (2006), whereas the oxygenated sesquiterpenes 1-epi-Cubenol, Spathulenol, $\alpha$-Cadinol and epi- $\alpha$-Muurolol were observed in plants collected from Antonina-PR (Bernuci et al., 2016).

Piper cernuum Vell., known as "pariparoba", is a native non-endemic species found in primary and secondary forests in Atlantic Tropical Areas (Flora do Brazil, 2018), which has been used in traditional medicine for stomach, liver, kidney and circulatory treatments (Mariot et al., 2007).

The essential oil produced by this species has the monoterpenes $\alpha$-pinene and $\beta$-pinene and the oxygenated sesquiterpenes spathulenol, epi- $\alpha$-muurolol, $\alpha$-muurolol, caryophyllene oxide and $\alpha$-cadinol, which have shown high leishmanicidal activity and moderate anti $M$. tuberculosis activity (Bernuci et al., 2016). The sesquiterpenes dihydro- $\beta$-agarofuran and 10 -epi- $\gamma$-eudesmol, besides the monoterpenes $\alpha$-pinene and camphene, were the main constituents and have shown antibacterial activity (Perigo et al., 2016).

Furthermore, Girola et al. (2015) verified induced apoptosis in melanoma cells by a camphene compound isolated from $P$. cernuum essential oil.

Piper diospyrifolium Kunth., a semi-heliophilous perennial shrub regionally known as "joao-borandi", is found in humid areas of dense low montain forests and in lowland forests in Rio de Janeiro, São Paulo and Parana (Brazil) (Guimaraes et al., 2006). The 
essential oil composition presented the sesquiterpenes selin-11-en-4- $\alpha$-ol, germacrene B and $\alpha$-selinene, with inhibitory growth potential of Leishmania forms (Perigo et al., 2016). Sesquiterpenes were also related to antifungal potential against Candida species (Vieira et al., 2011).

These species have a common characteristic, the high environmental regulation of essential oil production (Bergo, 2010; Oliveira et al., 2013; Silva et al., 2013; Perigo et al., 2016), which results in differences in yield and composition according to the plant collection location. Even in the same location, high variability can be found in the essential oil production of Piper species because of natural propagation through seeds. The development of vegetative protocols could be very useful for these species in order to maintain the essential oil yield and quality of selected plant materials for cultivation.

Some vegetative propagation protocols have been developed for Piper using different types of propagules (Cunha et al., 2015; Gomes and Krinski, 2016a), substrates, luminosity and seasonality (Mesquita et al., 2005; Dousseau, 2009; Gomes and Krinski, 2016b; Pacheco et al., 2016; Gasparetto et al., 2017). However, there is a lack of information on propagation for the great majority of species, especially for the three species included in this study.

The objective of this study was to evaluate the root production of Piper arboreum, P. cernuum and
P. diospyrifolium after treatment with indole butyric acid to develop cultivation protocols and reduce extractivism.

\section{MATERIALS AND METHODS}

The botanical specimens used in this study were collected in April, 2016 in the "Biological Reserve Bom Jesus", Parana state (Brazil), located at 25²9'69.3" S and $49^{\circ} 00^{\prime} 84.4^{\prime \prime}$ W, at sea level. Samples of the botanical species were deposited in the herbarium of the "Botanical Museum", located in the "Botanic Garden of Curitiba" under the numbers MBM 396412 (Piper arboreum Aubl.), MBM 396416 (Piper cernuum Vell.) and MBM 396413 (Piper diospyrifolium Kunth.).

The plant material was collected and moistened in the field until the stem cutting preparation. Cuttings with a length between $10-12 \pm 2 \mathrm{~cm}$ and a diameter of $6 \pm 2 \mathrm{~mm}$ were prepared maintaining one pair of leaves with half of the leaf area. Before the rooting treatments, the stem cuttings were kept in running water for $5 \mathrm{~min}$.

This experiment was conducted with a completely randomized design for each species, comparing five treatments [immersion in hydro alcoholic solutions containing 0,$500 ; 1,000 ; 1,500 ; 2,000$ and 3,000 mg $\mathrm{L}^{-1}$ of indole butyric acid (IBA) for $10 \mathrm{~s}$ ], with four replications with 10 cuttings each. After the treatment, the stem cuttings were transferred to polypropylene

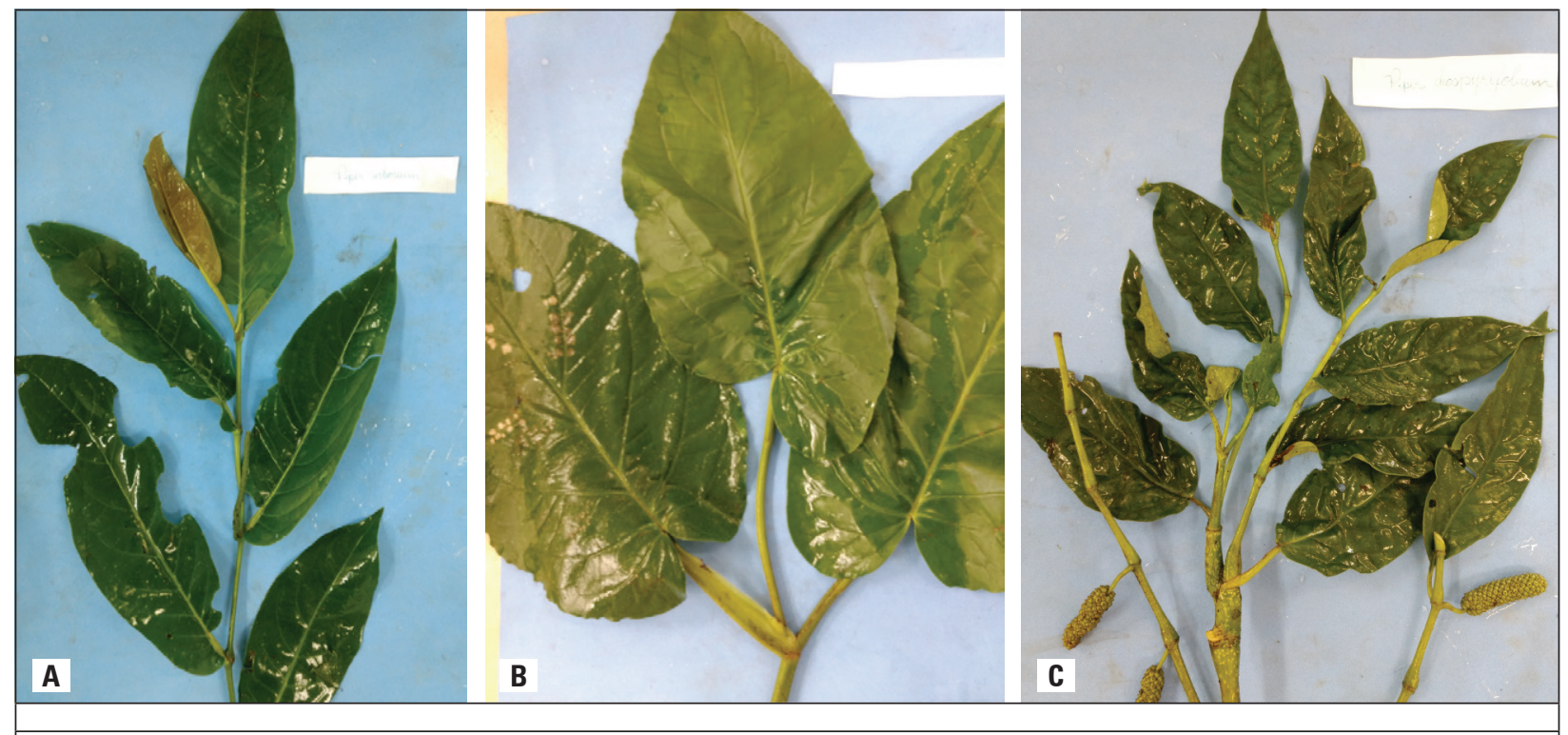

Figure 1. Semihardwood stems from A. P. arboretum; B. P. cernuum; and C. P. diospyrifolium (Ferriani, 2016). 
tubes $\left(53 \mathrm{~cm}^{3}\right)$ containing the commercial substrate Tropstrato $\mathrm{HP}^{\circledR}$ maintained in a greenhouse with intermittent misting, relative humidity around $80 \%$ and temperatures ranging for $20-30^{\circ} \mathrm{C}$ for $90 \mathrm{~d}$.

The rooting percentages, number and average length of the three main roots, foliar retention, sprout and shoot mortality were evaluated. The data was submitted to homogeneity analysis with Bartlett's test and the analysis of variance and regression using the statistical software Assistat (Silva et al., 2016).

\section{RESULTS AND DISCUSSION}

In all analyzed species, the rooting response were positively affected by the plant growth regulator indole butyric acid. P. arboreum reached 70\% rooting percentage of cuttings when the highest IBA concentration was used (Fig. 2).

Variables related to rooting response, such as leaf retention percentages, number and length of roots were negatively affected by the IBA concentrations over $1,500 \mathrm{mg} \mathrm{L}^{-1}$, which may indicate a phytotoxicity effect. These results may be related to the intrinsic capacity of natural vegetative propagation with stolons, as pointed by Souza et al. (2009).

In this species, leaf loss at high concentrations of an exogenous regulator affect adventitious rooting because mature leaves act as a source of carbohydrates and cofactors as verified in P. hispidum, which presented higher numbers of sprouts and roots in cuttings that maintained a higher number of leaves (Cunha et al., 2015). The rooting of the P. cernuum cuttings showed an upward behavior with a maximum of $45 \%$ in $3,000 \mathrm{mg} \mathrm{L}^{-1}$ of IBA, and it was possible to verify that the highest concentrations also promoted the highest percentages of this variable, limited by the plant regulator treatments (Fig. 3).

The percentage of sprout shoots showed a linear increase as a function of the higher IBA concentration. It was not possible to associate the behavior of the leaf retention variable to any treatment whose overall mean was $25.4 \%$. However, for the number and root length variables, it was possible to verify the tendency to increase the values up to the limit of 2,000 $\mathrm{mg} \mathrm{L}^{-1}$. These results suggest that doses containing higher concentrations may trigger phytotoxic effects, leading to a reduction of the quality of the adventitious root system.
In comparison with other species from the same family, Piper cernuum presents a greater leaf area (almost five times greater), which represents higher metabolic intakes and losses. Thus, in this case, the leaf loss was associated with an increase in the percentage of shoots that promoted the translocation of photoassimilates to a critical level, from which there was a reduction in the number and length of the roots.

The $P$. diospyrifolium cuttings reached a percentage of rooting of $70 \%$, being influenced by the application of IBA treatments up to the concentration of 1,500 $\mathrm{mg} \mathrm{L}^{-1}$, since there was a reduction in the means of this variable with the higher IBA concentrations (Fig. 4).

The percentages of sprouts and leaf retention indicate that high doses of the plant regulator may have caused foliar abscission, interfering in propagule sprouting and, consequently, in root induction and the root length variable. Vignolo et al. (2014) verified a similar behavior for the cuttings of three blackberry (Rubus spp.) cultivars, where the presence of leaves positively affected the sprouting and rooting in all of the evaluated cultivars.

The number of roots varied linearly as a function of the plant regulator treatments. In Piper mikanianum, Pescador et al. (2007) related an increase in the rooting rate with the foliar maintenance and sprout formation in the cuttings. According to Hartmann et al. (2002), mature leaves and sprouting development increase the synthesis of cofactors related to the rooting process.

These results show the importance of the specific evaluation of rooting production for each Piper species since they present different responses in root induction and development.

The formation of an adventitious rooting system is dependent on the endogenous level of hormones and other rooting promoters (Hartmann et al., 2002). In $P$. hispidum for example, the rooting of stem cuttings reached percentages greater than $80 \%$ without the application of exogenous auxins (Cunha et al., 2015), and stem cuttings from $P$. amalago reached only $22 \%$ under the same auxin concentration (Gomes and Krinski, 2016a).

Other studies that consider the seasons for plant collection are recommended for the root production of these species. 


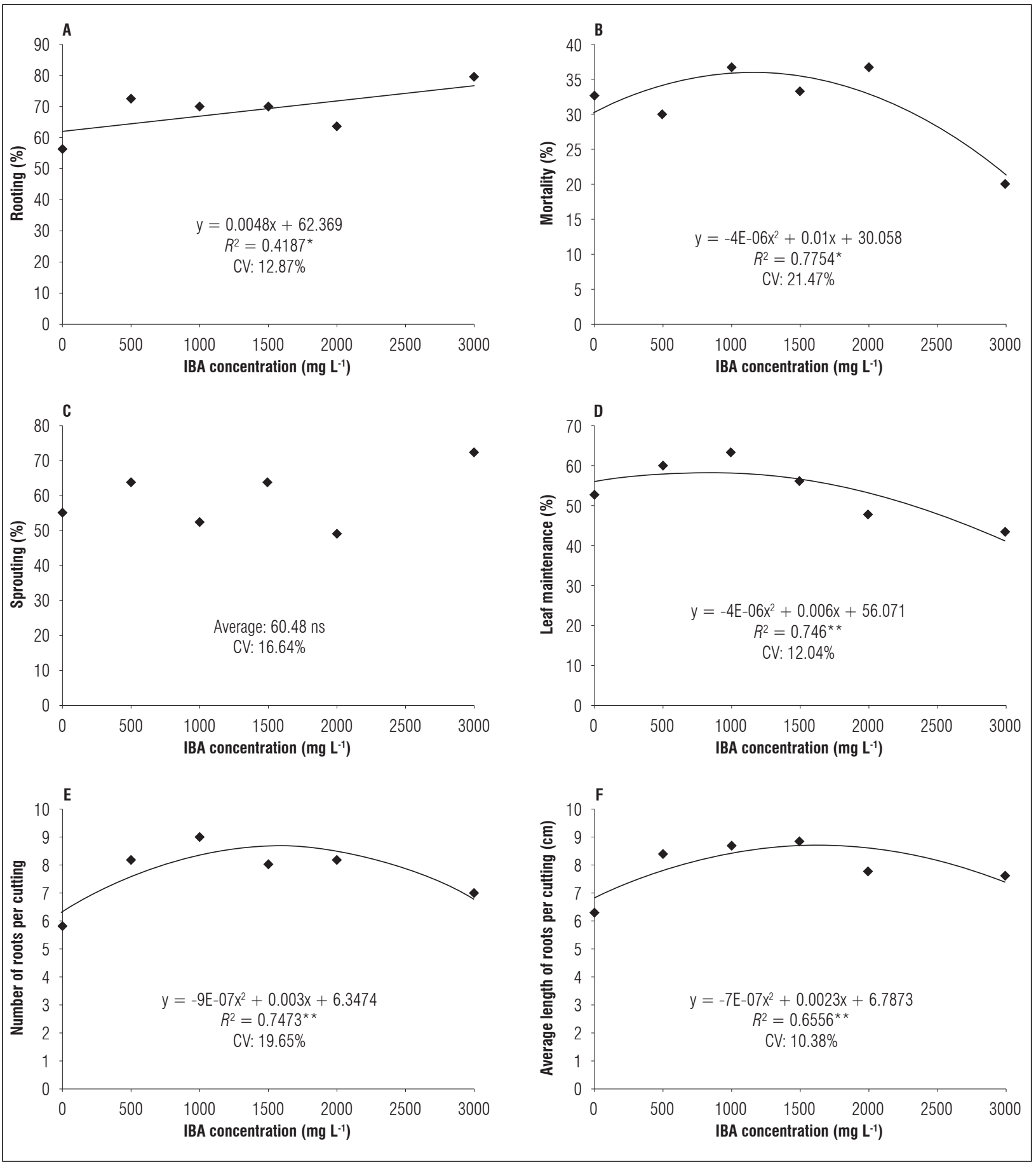

Figure 2. Rooting percentage, mortality, sprouting, leaf retention, number and average length of roots in the $P$ arboreum cuttings. * *Significant at $1 \%$ probability according to polynomial regression analysis; * significant at $5 \%$ probability according to polynomial regression analysis. ns: not significant. CV: coefficient of variation. 


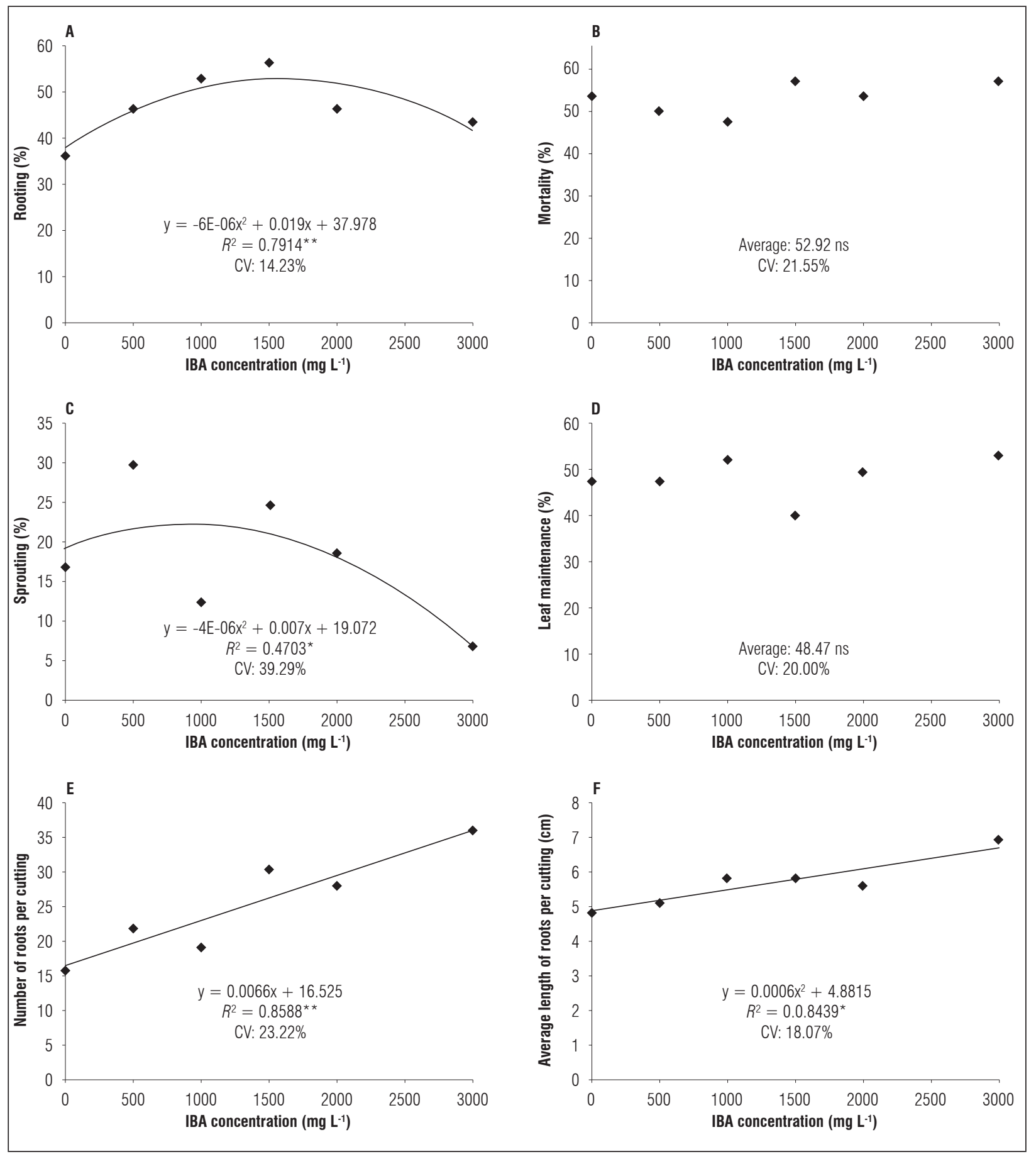

Figure 3. Rooting percentage, mortality, sprouting, leaf retention, number and average length of roots in the $P$. cernuum cuttings. * ${ }^{*}$ Significant at $1 \%$ probability according to polynomial regression analysis; *Significant at $5 \%$ probability according to polynomial regression analysis. ns: not significant. CV: coefficient of variation. 

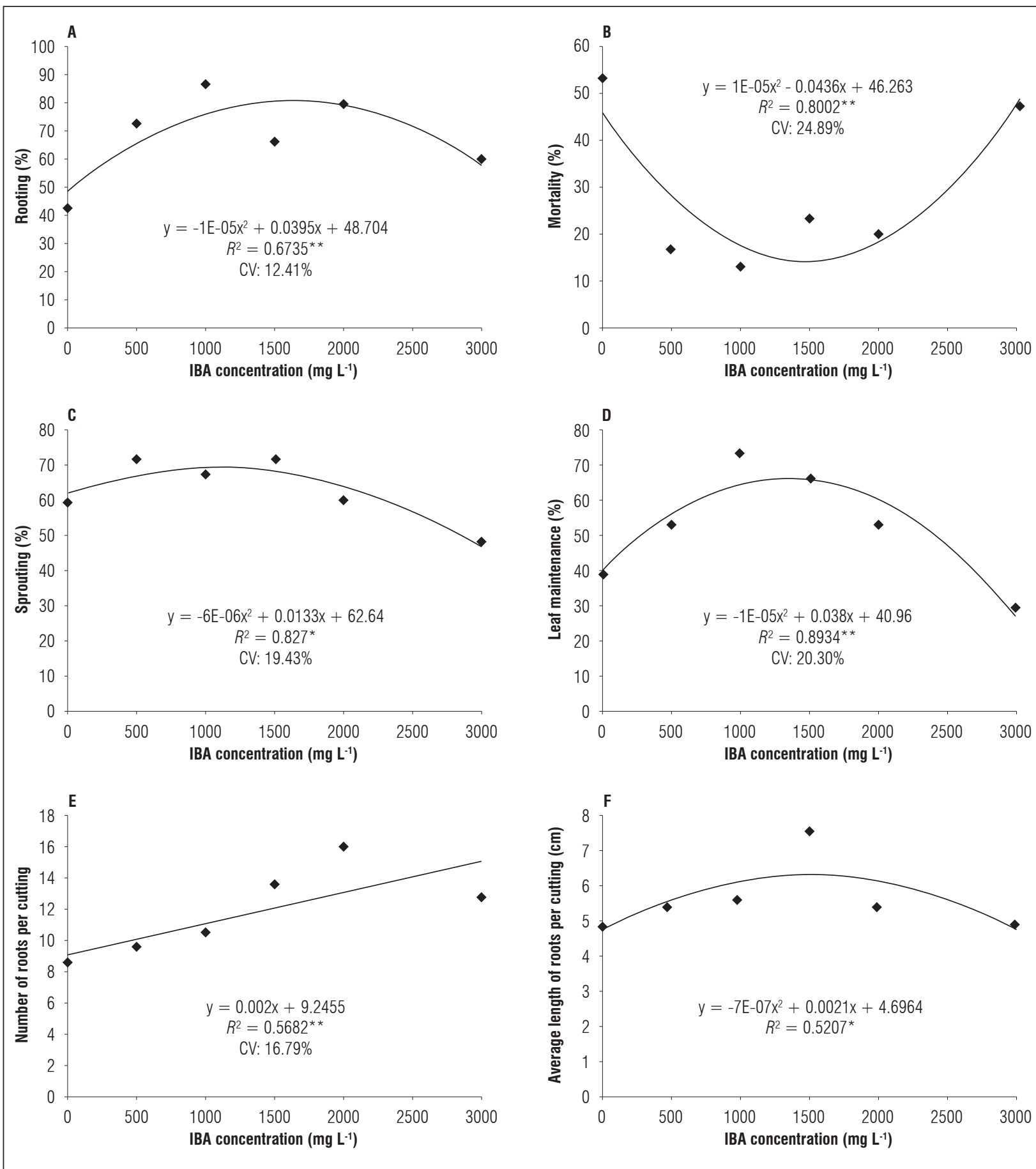

Figure 4. Rooting percentage, mortality, sprouting, leaf retention, number and average length of roots in the $P$. diospyrifolium cuttings. * Significant at $1 \%$ probability according to polynomial regression analysis; *Significant at $5 \%$ probability according to polynomial regression analysis. ns: not significant. CV: coefficient of variation. 
The present study provides unprecedented information on the propagation of these Piper species, which will help establish protocols that guarantee sustainable cultivation practices since the current use of raw material is exclusively obtained with extractivism.

\section{CONCLUSIONS}

All of the evaluated species presented an increase in root production after treatment with indole butyric acid. The rooting percentages reached averages of $67.5 \%$ for $P$. arboreum, $51.6 \%$ for P. cernuum and $50.4 \%$ for $P$. diospyrifolium.

These positive results show the importance of specific studies on the domestication of Piper native species for crops development.

\section{AKNOWLEDGMENTS}

This research was supported by funding from the Agronomy Graduate Program of University of Parana. The authors are grateful for the funding provided by CAPES (Brazilian Agency Foundation for Research), which sponsored the second author's graduate studies. We also gratefully acknowledge the "Environment Institute of Parana State" for providing the license to collect and transport the plant material and "The Botanic Garden of Curitiba", Parana State, for species identification.

Conflict of interests: the manuscript was prepared and reviewed with the participation of the authors, who declare that there exists no conflict of interest that puts the validity of the presented results at risk.

\section{BIBLIOGRAPHIC REFERENCES}

Bergo, C.L. 2010. Estudos agronômicos e fitoquímicos de Piper hispidinervum C.DC. e Piper aduncum L. para produção de safrol e dilapiol. Ph.D. thesis. Universidade Federal do Parana, Curitiba-PR, Brazil.

Bernuci, K.Z., C.C. Iwanaga, C.M.M. Fernandez-Andrade, F.B. Lorenzetti, E.C. Torres-Santos, V.S. Faiões, J.E. Gonçalves, W. Amaral, C. Deschamps, R.B.L. Scodro, R.F. Cardoso, V.P. Baldin, and D.A.G. Cortez. 2016. Evaluation of chemical composition and antileishmanial and antituberculosis activities of essential oils of piper species. Molecules 21(1698), 3-12.

Cunha, A.L.B., F.C.M. Chaves, A.C. Batista, and A.F. Hidalgo. 2015. Propagação vegetativa de estacas de Piper hispidum Sw. em diferentes substratos. Rev. Bras. Plantas Med. 17(4), 685-692.10.1590/1983-084X/14_113

Dousseau, S. 2009. Propagação, características fotossintéticas, estruturais, fitoquímicas e crescimento inicial de Piper aduncum L. (Piperaeae). Tesis. Universidade Federal de Lavras, Lavras-MG, Brazil.

Flora do Brasil. 2018. Piperaceae. In: Jardim Botânico do Rio de Janeiro, http://floradobrasil.jbrj.gov.br/reflora/floradobrasil/FB12735; consulted: March, 2018.

Gasparetto, A., A.B. Cruz, T.M. Wagner, T.J. Bonomini, R. Correa, and A. Malheiros. 2017. Seasonal variation in the chemical composition, antimicrobial and mutagenic potential of essencial oils from Piper cernuum. Ind. Crops Prod. 95, 256-263. Doi: 10.1016/j. indcrop.2016.10.030

Girola, N., C.R. Figueiredo, C.F. Farias, R.A. Azevedo, A.K. Ferreira, S.F. Teixeira, T.M. Capello, E.G.A. Martins, A.L. Matsuo, L. Travassos, and J.H.G. Lago. 2015. Camphene isolated from essential oil of Piper cernuum (Piperaceae) induces intrinsic apoptosis in melanoma cells and displays antitumor activity in vivo. Biochem. Biophys. Res. Com. 467(4), 928-934. Doi: 10.1016/j. bbrc.2015.10.041

Gomes, E.N. and D. Krinski. 2016a. Propagação vegetativa de Piper amalago L. (Piperaceae) em função de tipos de estaca e substratos. Cult. Agron. 25(2), 199-210.

Gomes, E.N. and D. Krinski. 2016b. Propagação vegetativa de Piper umbellatum L. (Piperaceae) em função de substratos e comprimentos de estacas. Sci. Agrar. 17(3), 31-37.

Guimaraes, E.F. and D. Monteiro. 2006. Piperaceae na reserva biológica de Poço das antas, Silva Jardim, Rio de Janeiro, Brasil. Rodriguésia 57(3), 567-587. Doi: 10.1590/2175-7860200657312

Hartmann, H.T., D.E. Kester, F.T. Davies Junior, and R.L. Geneve. 2002. Principles of propagation by cuttings. pp. 280-343. En: Hartmann, H.T., F.T. Davies, and D.E. Kester (eds.). Plant propagation: principles and practices. $7^{\text {th }}$ ed. Prentice Hall, Englewood Cliffs, NJ, USA.

Lopes, J.J., C. Marx, R. Ingrassia, J.N. Picada, P. Pereira, and A.B.F. Ferraz. 2012. Neurobehavioral and toxicological activities of two potentially CNS-acting medicinal plants of Piper genus. Exp. Toxicol. Pathol. 64, 9-14. Doi: 10.1016/j.etp.2010.05.012

Mariot, A., J.V. Odorizzi, J. Nascimento, and M.S. Reis. 2007. Uso e conservação de Piper cernuum Vell. (Piperaceae) na Mata Atlântica: II. Estrutura demográfica e potencial de manejo em floresta primária e secundária. Rev. Bras. Plantas Med. 9(1), 13-20.

Mesquita, J.M.O., C. Cavaleiro, A.P. Cunha, J.A. Lombardi, and A.B. Oliveira. 2005. Estudo comparativo dos óleos voláteis de algumas espécies de 
Piperaceae. Rev. Bras. Farmacogn. 15, 6-12. Doi: 10.1590/S0102-695X2005000100003

Oliveira, G.B., D.L. Moreira, A.D.R. Mendes., E.F. Guimarães, L.S. Figueiredo, M.A.C. Kaplan, and E.R. Martins. 2013. Growth study and essential oil analysis of Piper aduncum from two sites of Cerrado biome of $\mathrm{Mi}$ nas Gerais State, Brazil. Rev. Bras. Farmacogn. 23(5), 743-753. Doi: 10.1590/S0102-695X2013000500005

Pacheco, F.V., R.P. Avelar, I.C.A. Alvarenga, S.K.V. Bertolucci, A.A. Alvarenga, and J.E.B.P. Pinto. 2016. Essential oil of monkey-pepper (Piper aduncum L.) cultivated under different light environments. Ind. Crops Prod. 85, 251-257. 10.1016/j.indcrop.2016.03.016

Pereira, A.C.R.L., J.V. Oliveira, M.G.C. Gondim-Junior, and C.A.G. Câmara. 2008. Atividade inseticida de óleos essenciais e fixos sobre Callosobruchus maculatus (Fabr., 1775) (Coleoptera: Bruchidae) em grãos de caupi [Vigna unguiculata (L.) Walp.]. Ciênc. Agrotec. 32(3), 717724. Doi: 10.1590/S1413-70542008000300003

Perigo, C.V., R.B. Bernacci, E.F. Guimaraes, L.L. Haber, R. Facanali, M.A.R. Vieira, V. Quecini, and M.O.M. Marques. 2016. The chemical composition and antibacterial activity of eleven Piper species from distinct rainforest areas in Southeastern Brazil. Crops Natural Prod. 94, 528-539. Doi: 10.1016/j.indcrop.2016.09.028

Pescador, R., A.C. Voltoni, C.G. Rolaardi, and F.A. Rosa. 2007. Estaquia de pariparoba-do-Rio Grande do Sul sob efeito do ácido indol-butírico em dois substratos. Sci. Agric. 8(4), 391-398. Doi: 10.5380/rsa.v8i4.9886

Potzernheim, M., H.R. Bizzo, T.S. Agostini-Costa, R.F. Vieira, M. Carvalho-Cilva, and L.A.M.B. Gracindo 2006. Chemical characterization of seven Piper species
(Piperaceae) from Federal District, Brazil, based on volatile oil constituents. Rev. Bras. Plantas Med. 8, 10-12.

Silva, R.J.F., A.C.A. Aguiar-Dias, K.C.F. Faial, and M.S. Mendonça. 2016. Caracterizacao farmacognostica de Piper arboreum e P. tuberculatum (Piperaceae). Acta Amaz. 46(2), 195-208. Doi: 10.1590/ S0044-59672007000200004

Silva, F.A.S. and C.A.V. Azevedo. 2016. Comparison of means of agricultural experimentation data through different tests using the software assistat. Afr. J. Agric. Res. 37(11), 3527-3531.

Silva, A.L.L., F.C.M. Chaves, R.C. Lameira, and R.C. Bizzo. 2013. Rendimento e composição do óleo essencial de $P$. aduncum L. cultivado em Manaus, AM, em função da densidade de plantas e épocas de corte. Rev. Bras. Plantas Med. 15(4), 670-674. Doi: 10.1590/ S1516-05722013000500007

Souza, L.A.d., I.S. Moscheta, K.S.M. Mourão, A.L.M. Albiero, M.d.C. Iwazaki, J.H.G.d. Oliveira, and S.M.d. Rosa. 2009. Vegetative propagation in Piperaceae species. Braz. Arch. Biol. Biotechnol. 52(6), 1357-1361. Doi. 10.1590/S1516-89132009000600006

Vieira, S.C.H., L.F. Paulo, T.I.E. Svidzinski, B.P. Dias Filho, C.V. Nakamura, A. Souza, M.C.M. Young, and D.A.G. Cortez. 2011. Antifungal activity of $P$. diospyrifolium Kunth, (Piperaceae) essential oil. Braz. J. Microbiol. 42, 1001-1006. Doi: 10.1590/S1517-83822011000300020

Vignolo, G.K., L. Picolotto, M.A. Goncalves, I.S. Pereira, and L.E.C. Antunes. 2014. Presença de folhas no enraizamento de estacas de amoreira-preta. Cienc. Rural 44(3), 467-472. Doi: 10.1590/S0103-84782014000300013 